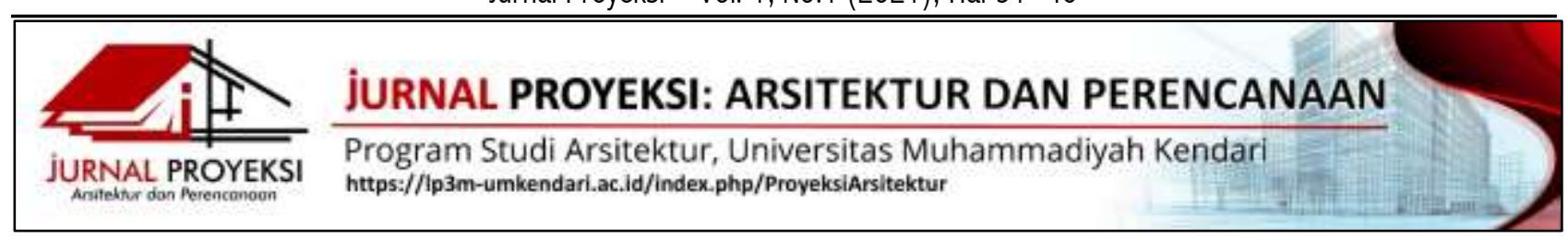

\title{
PENERAPAN ARSITEKTUR MORPHOSIS PADA GAME CENTER DI KOTA KENDARI
}

\author{
Mukhlis $^{1}$, Ilham ${ }^{2}$, Surya Baskara ${ }^{3 *}$ \\ 1,3 Program Studi Arsitektur, Fakultas Teknik, Universitas Muhammadiyah Kendari \\ 2 Program Studi Arsitektur, Fakultas Teknik, Universitas Halu Oleo Kendari \\ *surya.baskara@umkendari.ac.id
}

\begin{abstract}
INFORMASI ARTIKEL
Diterima Redaksi:

11 Agustus 2021

Revisi Akhir:

07 September 2021

Diterbitkan:

Cetak:

19 September 2021

Online

19 September 2021

\section{Abstract}

One of the advances in entertainment facilities and facilitation in the city of Kendari is progress in the internet (virtual world) and in the field of games. This can be seen with the emergence of various entertainment facilities that are engaged in internet cafes (internet cafes) and games. Game Center in Kendari with the Morphosis Architecture Approach is the process of making a container or place that is centered to provide entertainment about the development of games in Kendari City with the process of forming an innovative, iconic building and friendly to the urban environment. The basic concept of Game Center planning and design in Kendari City through interior and exterior structuring with an emphasis on innovative studies iconic buildings and friendly to the urban environment as a goal of the Game Center with the concept of Morphosis Architecture. Game Center Planning in Kendari with the Morphosis Architecture approach must be used in accordance with the functions outlined in the design reference so that it can have a positive impact both for the building manager, the government, the drafting of further references and the wider community.
\end{abstract}

Keyword: Game Center, Morphosis Architecture.

\section{Abstrak}

Salah satu kemajuan sarana dan fasilitasi hiburan di kota Kendari adalah kemajuan di bidang internet (dunia maya) dan di bidang game. Hal ini dapat dilihat dengan munculnya berbagai sarana hiburan yang bergerak dalam bidang warnet (warung internet) dan game. Game Center di Kendari dengan Pendekatan Arsitektur Morphosis adalah Proses pembuatan sebuah wadah atau tempat yang dipusatkan untuk memberikan hiburan tentang perkembangan game di Kota Kendari dengan proses pembentukan yang inovatif, bangunan ikonik dan ramah terhadap lingkungan perkotaan. Konsep dasar perencanaan dan perancangan Game Center di Kota Kendari melalui penataan interior dan eksterior dengan penekanan studi yang inovatif, bangunan ikonik dan ramah terhadap lingkungan perkotaan sebagai tujuan Game Center dengan konsep Arsitektur Morphosis. Perencanaan Game Center di Kendari dengan pendekatan Arsitektur Morphosis harus digunakan sesuai dengan fungsi yang telah digariskan dalam acuan perancangan sehingga dapat memberikan dampak yang positif baik bagi pengelola bangunan, pemerintah, penyusun acuan selanjutnya dan masyarakat secara luas.

Kata Kunci: Game Center, Arsitektur Morphosis.

\section{PENDAHULUAN}

\section{A. Latar Belakang}

Game (permainan) secara umum adalah sebuah aktivitas rekreasi dengan tujuan bersenang senang, untuk mengisi waktu luang, atau berolahraga ringan. Permainan biasanya dilakukan sendiri atau bersama-sama. Game semakin tahun semakin terjadi peningkatan didalamnya, namun yang terpenting adalah kepuasan dan keasikan yang didapatkan selama bermain game, apalagi sekarang game bisa dilakukan bersama team atau secara berkelompok. Game dapat dimainkan oleh siapapun tanpa terkecuali dari anak-anak, remaja, hingga orang yang sudah dewasa sekalipun. Bahkan game juga dimainkan oleh pria maupun wanita, karena game memiliki fungsi yang memberi kepuasan dalam memainkannya.

Kebutuhan akan hiburan merupakan salah satu kebutuhan rohani yang sangat berpengaruh dalam kehidupan manusia. Salah satu poin penting dalam pencapaian tersebut adalah peningkatan fasilitas hiburan. Berdasarkan hal tersebut kota Kendari berupaya memenuhi pengadaan sarana dan fasilitas pelayanan dan hiburan yang dapat 
memberikan kepuasan kepada masyarakat. Salah satu kemajuan sarana dan fasilitasi hiburan di kota Kendari adalah kemajuan di bidang internet (dunia maya) dan di bidang game. Hal ini dapat dilihat dengan munculnya berbagai sarana hiburan yang bergerak dalam bidang warnet (warung internet) dan game. Ada beberapa warnet yang juga khusus menyediakan game online sehingga para pengunjung yang ingin bermain game dapat mendatangi warnet tersebut. Seperti yang kita ketahui warnet dan game merupakan salah satu sarana untuk menyalurkan bakat dan hobi serta memacu kreativitas penggunanya.

Bila meninjau sarana hiburan bergerak dalam bidang internet dan game di Kendari, pada umumnya para pengusaha warnet atau game online mencari tempat di pusat-pusat aktivitas atau pusat perdagangan yang merupakan konsentrasi penduduk tinggi. Mahalnya harga tanah di tempattempat yang di anggap strategis untuk kegiatan perdagangan dan semakin terbatasnya lahan yang tersedia pada lokasi tersebut, mengakibatkan sulitnya para pengusaha untuk membangun suatu tempat usaha. Umumnya mereka menyewa ruko dengan standart ruang yang kurang memadai dan jika dilihat dari sisi ilmu Arsitektur, warnet dan pusat game yang ada di kota Kendari baik itu desain interior maupun exterior belum dapat memberikan kenyamanan bagi para pengguna internet dan pemain game (gamer).

Dengan adanya gedung Game Center di Kendari, maka para peminat game online maupun offline dapat berkumpul untuk bermain ataupun bertanding dengan fasilitas yang telah disiapkan. Diharapkan dengan adanya wadah ini, dapat meningkatkan kemudahan bagi masyarakat pengguna warnet dan game di kota Kendari. Dengan memberikan fasilitas rekreasi atau hiburan kepada masyarakat umum serta meningkatkan apresiasi terhadap perkembangan teknologi computer.

Hal tersebut mengindikasikan perlu adanya gedung Game Center di Kendari yang dapat mewadahi segala kegiatan hiburan bagi pengunjung yang mengutamakan keamanan dan kenyamanan pada saat berada dalam maupun diluar gedung.

\section{B. Pertanyaan Penelitian}

Berdasarkan pada uraian latar belakang diatas, peneliti merumuskan pertanyaan penelitian yang ingin diketahui antara lain:

1. Bagaimana menentukan lokasi dan site pada perancangan Game Center di Kota Kendari?

2. Bagaimana pendekatan Arsitektur Morphosis pada desain fisik gedung Game Center di Kendari yang dapat mengekspresikan karakter fungsi bangunan sebagai pusat game?

\section{Tujuan Pembahasan}

Adapun tujuan dari pembahasan yang akan dicapai yaitu:
1. Untuk menentukan lokasi dan site pada perancangan Game Center di Kota Kendari.

2. Untuk mengetahui pendekatan Arsitektur Morphosis pada desain fisik gedung Game Center di Kendari yang dapat mengekspresikan karakter fungsi bangunan sebagai pusat game.

\section{Sasaran, Lingkup dan Batasan Pembahasan}

Adapun sasaran pembahasan pada penelitian ini adalah menyusun suatu bentuk perancangan yang meliputi konsep makro dan mikro yang lebih mengarah pada perencanaan fisik gedung serta merencanakan pengadaan fasilitasfasilitas penunjang yang akan lebih mengembangkan fungsi gedung Game Center tersebut.

Lingkup pembahasan pada penelitian ini di arahkan pada pembahasan Arsitektur yang merupakan alternatif rancangan, perancangan tapak, tata fisik bangunan dan pola hubungan ruang.

Batasan pembahasan pada penelitian ini yaitu proses perancangan pada lokasi ini hanya terbatas pada gedung Game Center di kaitkan dengan aktifitas yang ada. Adapun hal-hal lain yang sifatnya lebih mengembangkan hanya akan diulas sebagai bahan pelengkap dan penunjang.

\section{TINJUAN PUSTAKA}

\section{A. Tinjauan Game Center}

Berbicara mengenai Game Center, menyangkut pula istilah-istilah yang terkait didalamnya seperti game, game online, game offline, jaringan internet, Local Area Network (LAN) dan bandwidth. (Prasetya, 2010).

Game Centre atau GameNet adalah jenis wirausaha yang menyewakan computer beserta sambungan internet dan LAN yang khusus digunakan untuk permainan dalam jaringan. Game Centre merupakan pengembangan dari warung internet (warnet), karena selain menyediakan koneksi internet, usaha ini juga menyediakan berbagai permainan komputer. Komputer yang disediakan oleh Game Center umumnya memiliki spesifikasi yang jauh lebih tinggi dari warnet, dan penyediaannya dalam jumlah yang lebih banyak.

\section{B. Tinjauan Arsitektur Morphosis \\ 1. Pengertian Morphosis}

Istilah morphosis yaitu proses pembentukan (dari bahasa latin) dan membentuk (dari bahasa Yunani, dari kata morphe, yaitu bentuk, tampilan luar). Morphosis merupakan praktek interdisipliner dalam desain dan penelitian yang menghasilkan inovasi, bangunan ikonik dan ramah lingkungan dalam perkotaan Arsitektur yang mengejutkan bebas dari bentuk tradisional dan bersifat klasik. Morphosis merupakan pencerahan arsitektur Pantai Barat Amerika. Proyek kantor ini menampilkan persimpangan perbaikan teknik

dengan pemahaman yang tepat tentang penggunaan bahan dan efek fenomenologis keragaman spasial. (Rifai, 2016). 


\section{Firma Arsitektur Morphosis}

Morphosis adalah sebuah firma arsitek berbasis di Santa Monica, didirikan pada 1972 oleh Thom Mayne dan Michael Rotondi, yang meninggal pada 1991. Mereka telah menyelesaikan 35 proyek besar pada 2004. Gedung terkenal yang dirancang oleh Morphosis termasuk: (Rifai, 2016)

$>$ Diamond Ranch High School

$>$ Higashi Azabu Tower

$>$ Cedars-Sinai Comprehensive Cancer Center Hospital

> University of Toronto Graduate House

Filosofi Morphosis yaitu suatu desain yang ditargetkan untuk menciptakan makna dalam arsitektur sebagai refleksi dari konteks fisik dan mental. Desain Morphosis 'mencerminkan warisan arsitek California Selatan seperti Rudolph Schindler dan Richard Neutra. Studio ini didirikan oleh Thom Mayne, Livio Santini, James Stafford, dan Michael Brickler pada tahun 1972. Mereka bergabung tiga tahun kemudian oleh Michael Rotondi. Kantor ini dinamai istilah Yunani, Morphosis, yang menandakan proses pembentukan atau berada dalam formasi. Oleh karena itu nama mencerminkan kesediaan untuk merangkul bentuk patung dan sensasi gerakan. Prinsip desain arsitektur morphosis yaitu sebagai berikut:

1) Karya yang sama dengan langgam deskontruksi tetapi masih memikirkan lingkungan disekitar bangunan.

2) Karya desain sangat bermain dengan berbagai bentuk.

3) Permainan bentuk mengikuti site dan memberi kesan yang highteknologi.

4) Lebih menonjolkan pada segi estetikanya.

5) Komposisi massa yang asimetris, bentuk tidak beraturan, dinding miring, dan penggunaan material beton serta kaca.

\section{METODOLOGI PENELITIAN}

Penelitian ini menggunakan pengamatan langsung, pengumpulan data dengan observasi langsung atau dengan pengamatan langsung adalah cara pengambilan data dengan menggunakan mata tanpa ada pertolongan alat standar lain untuk keperluan tersebut.

Serta Penelitian ini menggunakan studi literatur, melalui literatur-literatur dan buku-buku yang berkaitan dengan pembahasan untuk mendapatkan teori proses perancangan.

Untuk mencapai semua tujuan penilitian, peneliti perlu menentukan secara tepat jenis data atau informasi yang dibutuhkan karena dapat membantu peneliti menciptakan pertanyaan-pertanyaan dengan kategori respon yang sesuai. Berguna bagi perancang survei untuk memikirkan pertanyaan sebagai pengumpulan informasi dari kategori utama yakni opini, sikap, dan motif; kepercayaan dan persepsi, perilaku, fakta dan atribut, dan pengetahuan (Ulber Silalahi, 2009).

\section{HASIL PENELITIAN DAN PEMBAHASAN}

\section{A. Konsep Rancangan Tingkat Makro}

1. Lokasi dan Tapak

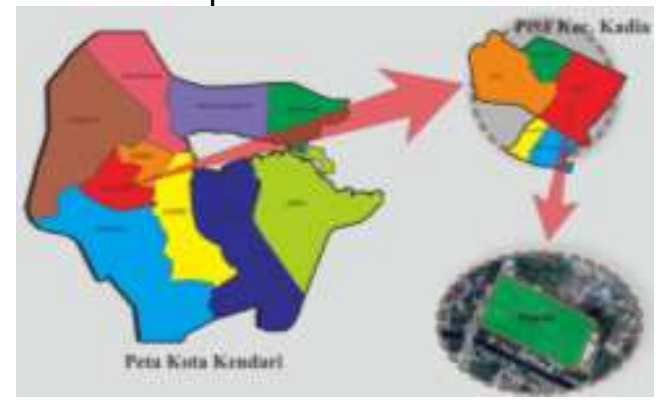

Gambar 1. Lokasi Game Center

(Sumber: Analisis Penulis 2020)

Kecamatan Kadia merupakan lokasi yang terpilih berdasarkan kriteria pemilihan lokasi dan sesuai dengan RTRW Kota Kendari sebagai pusat pemerintahan kota, pusat fasilitas umum skala Kota, kawasan permukiman perkotaan, kawasan perdagangan, jasa dan pariwisata, dengan luas tapak 4,34 H. Lokasi Gedung Game Center di Kot Kendari yang direncanakan ini berada di Jl. SaoSao dan Jl. Antero Hamara, Kec. Kadia, Kel. Bende.

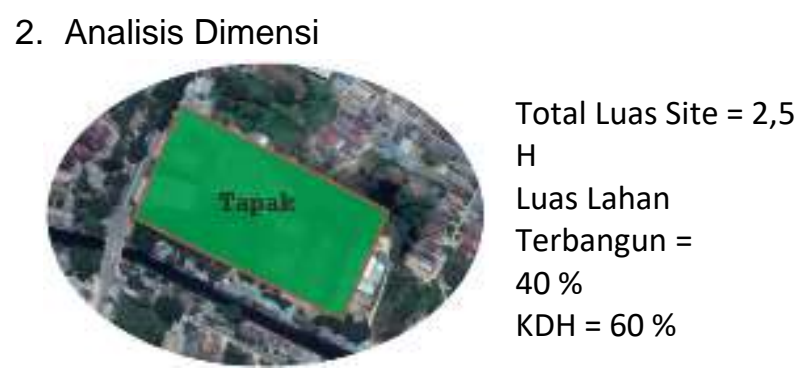

Gambar 2. Analisis Dimensi (Sumber: Analisis Penulis 2020)

3. Analisis Klimatologi

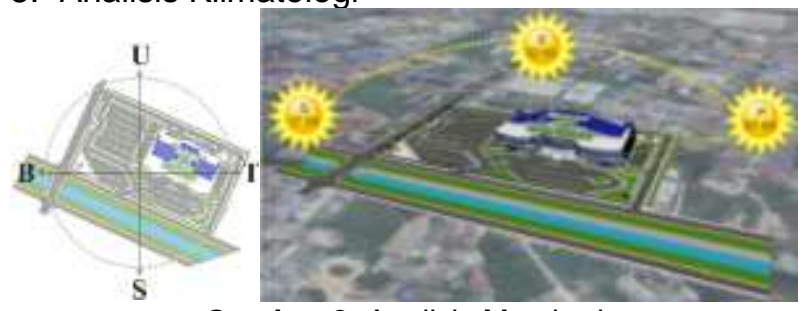

Gambar 3. Analisis Matahari

(Sumber: Analisis Penulis 2020)

Untuk efisiensi dan kenyamanan optimal yang berkaitan dengan panas dan cahaya matahari dilakukan perencanaan sebagai berikut:

a) Memposisikan orientasi bangunan yaitu orientasi menyangkut posisi bangunan pada site dimana arah memanjang dihadapkan ke arah utara dan selatan.

b) Penggunaan material yang bisa menyerap panas, khususnya pada bagian bagunan yang 
berpotensi mendapat sinar matahari paling banyak

c) Penanaman vegetasi sebagai sun-shading pada lansekap.

d) Penggunaan ornamen yang bisa berfungsi ganda, bukan hanya sebagai faktor estetika tetapi sebagai shadding sinar matahari

e) Memaksimalkan sinar matahari sebagai sumber pencahayaan alami dengan menggunakan dinding kaca.

\section{Analisis Hujan}

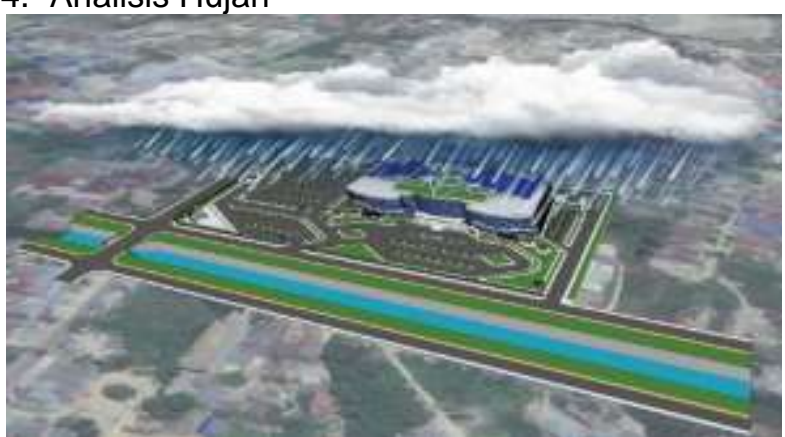

Gambar 4. Analisis Hujan

(Sumber: Analisis Penulis 2020)

Dengan tingkat intensitas curah hujan yang cukup tinggi di Kota Kendari, maka akan mempengaruhi model dan konstruksi struktur atap bangunan serta pemilihan material yang akan diaplikasikan kebangunan. Untuk itu maka pendekatan yang digunakan yaitu:

a) Kemiringan atap sedang untuk memudahkan pengaliran air hujan.

b) Penerapan green roof sebagai salah satu teknologi dari arsitektur berkelanjutan.

c) Finishing permukaan tanah diberikan permainan ketinggian untuk menyalurkan air ke ruang water tank bawah dan disalurkan ke ruang - ruang untuk dimanfaatkan kembali seperti untuk menyiram kloset, urinoir dan $\mathrm{RTH}$.

d) Penggunaan teknologi biopori sebagai salah satu alternatif untuk menghindari terjadinya genangan air pada saat musim penghujan dan dialirkan ke tanah.

5. Angin

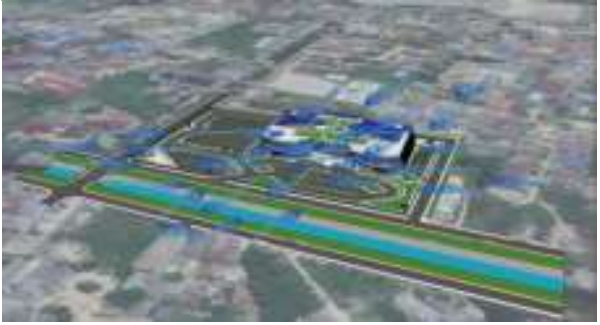

Gambar 5. Analisis Angin

(Sumber: Analisis Penulis 2020)
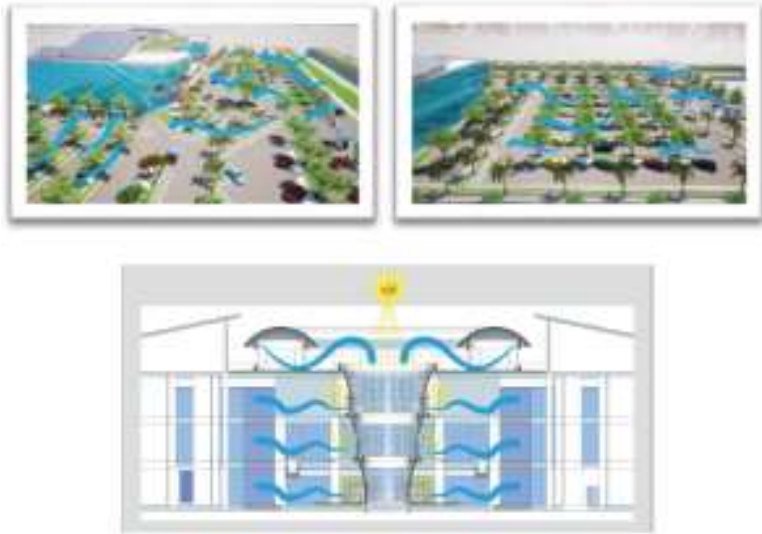

Gambar 6. Penetaan vegetasi terhadap angin dan membuat bukaan pada dinding

(Sumber: Analisis Penulis 2020)

\section{Analisis Arah Pandang (View)}

Solusi Orientasi View dengan nilai tema terbuka dan jujur, yaitu ke luar bangunan memanfaatkan tinggi bangunan dengan lingkungan sekitar serta maksimalkan pandangan ke luar dengan keterbukaan bangunan maupun layerin transparan.

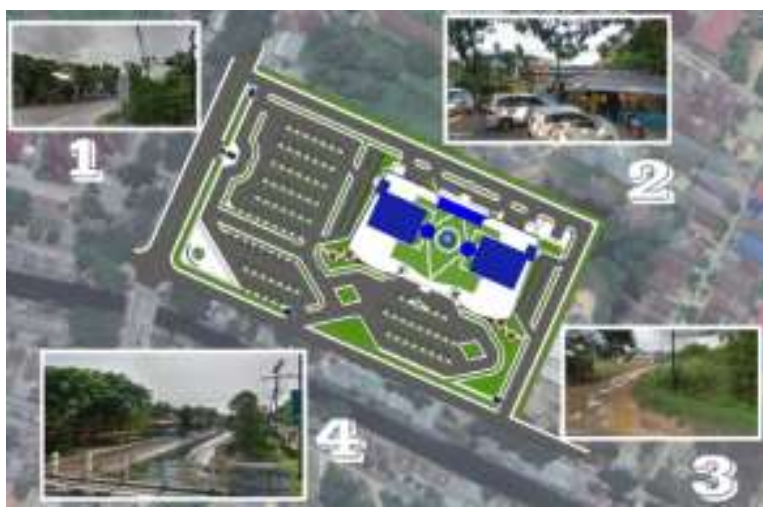

Gambar 7. Analisis Arah Pandang ke Luar (Sumber: Analisis Penulis 2020)

Sedangkan view ke luar bangunan disesuaikan dengan kondisi lingkungan sekitar serta menonjolkan bentuk bangunan yang baru dan indah.

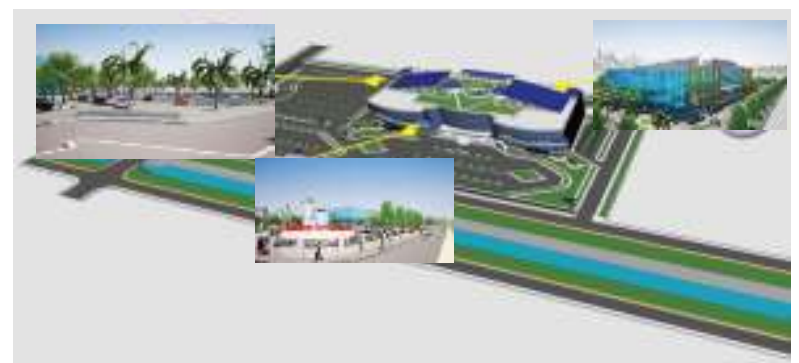

Gambar 8. Analisis Arah Pandang Ke Dalam (Sumber: Analisis Penulis 2020)

7. Analisis Kebisingan

Kebisingan merupakan efek suara yang dihasilkan oleh banyak faktor seperti suara yang berasal dari kendaraan. Untuk mengurangi 
kebisingan tersebut ada beberapa cara yang dapat diterapkan yaitu :

a) Pengaturan jarak bangunan dengan jalan

b) Panggunaan pohon yang tepat serta pengaturan jarak pohon pada tapak

c) Penggunaan material akustik bangunan

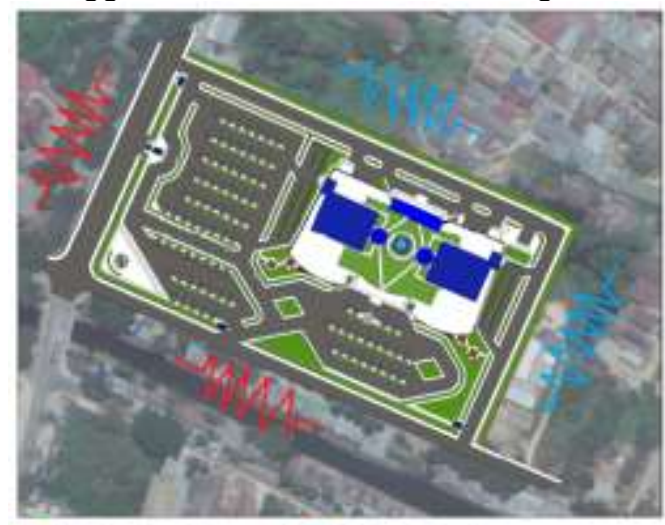

Bising Rendah $\quad$ Bising Tingyi

Gambar 9. Analisis Kebisingan

(Sumber: Analisis Penulis 2020)

\section{Analisis Sirkulasi}

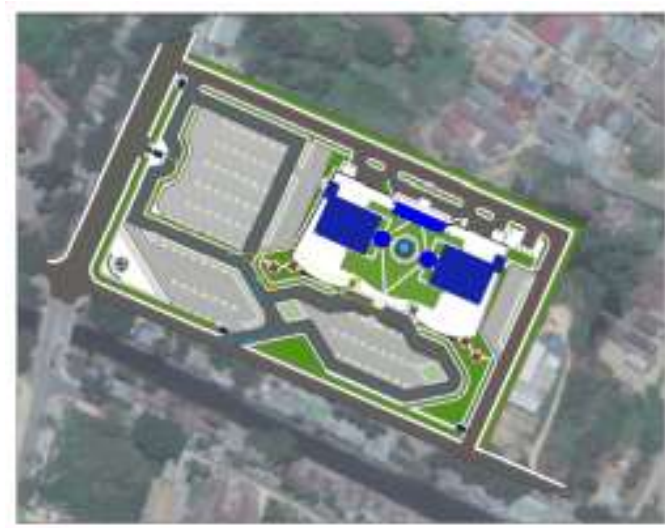

Sirkulasi Pengunjung dan pengelota

Sirkulasi Service Dan Emum

Sirkulasi Pejalan Kaki

Gambar 10. Analisis Srkulasi

(Sumber: Analisis Penulis 2020)

Sirkulasi adalah prasarana penghubung vital yang menghubungkan berbagai kegiatan dan penggunaan dalam sebuah tapak. Pengalaman berbeda-beda saat menelusuri sebuah tapak, dapat diciptakan melalui perubahan-perubahan dalam sistem sirkulasinya.

Sistem sirkulasi menggambarkan seluruh pola-pola pergerakan kendaraan dan pejalan kaki di dalam dan keluar-masuk tapak. Selain itu, sistem sirkulasi dalam tapak juga menghubungkan tapak tersebut dengan jaringan sistem sirkulasi di luar tapak.

9. Analisis Penzoningan

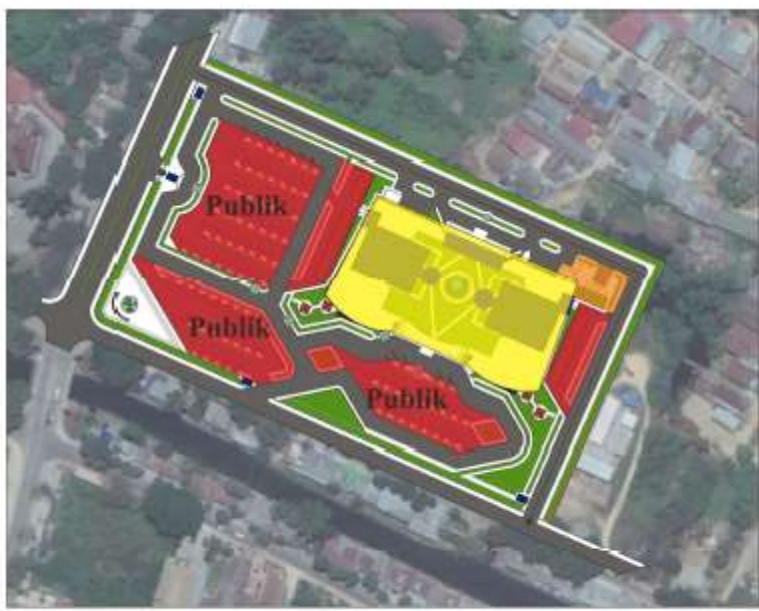

Publik

Semi Publik

Service

Gambar 11. Zoning Tapak

(Sumber: Analisis Penulis 2020)

Penzoningan dilakukan dengan pengelompokan kegiatan yang sama terhadap kondisi tapak dan kriteria zona penzoningan. Zona Penzoningan terbagi atas:

a) Publik : merupakan zona yang berhubungan secara langsung dengan pengunjung.

b) Semi public : merupakan peralihan antara zona pengelola dan pengunjung.

c) Servis : merupakan zona yang berhubungan erat dengan kegiatan service

\section{B. Konsep Perancangan Tingkat Mikro}

1. Konsep Bentuk dan Tampilan Bangunan

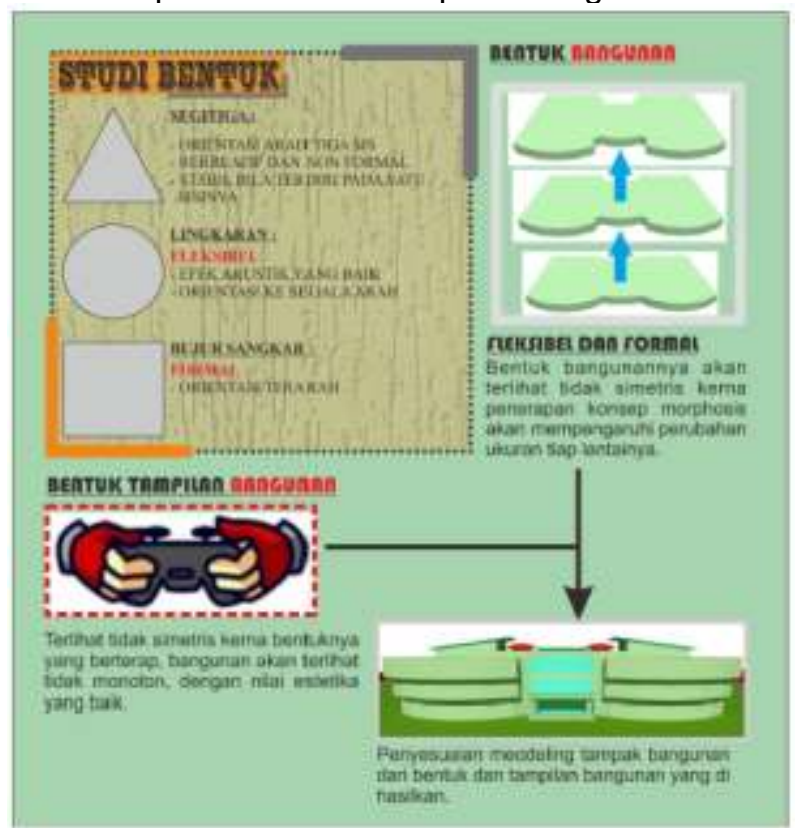

Gambar 12. Konsep Bentuk

(Sumber: Analisis Penulis 2020) 


\section{Skema Tampilan Bangunan}

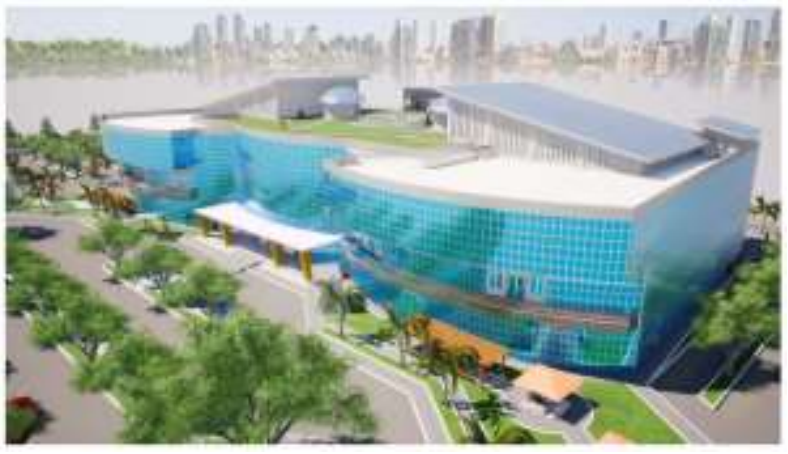

Gambar 13. Tampilan bangunan

(Sumber : Analisis Penulis 2020)

Penampilan Bagunan dibuat terap dan balkon serta oferstrek yang dilengkapi elemen pembayang yang mel ekat pada tampilan bangunan hingga bangunan terliat menarik oleh pengamat. Penampilan Bagunan dibuat tidak simetris dan membentuk sebua lenkungan agar terlihat berirama pada sisi depan bangunan hinga pengamat memandang bangunan dengan nilai estetika yang baik.

\section{Konsep Standar Besaran Ruang}

Standar-standar yang digunakan pada perencanaan Game Center di Kendari di dasarkan pada:

1) NAD : Neufert Architect Data

2) BPDS : Building Planning and Design Standard 3) A : Asumsi

Berdasarkan hasil perhitungan besaran ruang, maka dapat ditentukan luas area terbangun dan luas area bukaan dengan dasar pertimbangan Building Of Coverage (BOC) $=40 \%: 60 \%$. Berikut besaran ruang pada site dan massa terbangun untuk penentuan luas site yang dibutuhkan :

Dari total Keseluruhan luas lantai terbangun dibagi dengan tiga lantai (perencanaan lantai), maka didapatkan hasil rata-rata:

- BC (Building Coverage) $=40 \%: 60 \%$

Area Terbangun $=40 \%(B C)$

Area Tidak Terbangun $=60 \%(\mathrm{OS}=$ Open Space)

- $\quad \mathrm{BC}=$ Total Luas Ruang $=10.615,7 \mathrm{~m} 2$

$\mathrm{BC}=10.615,7 \mathrm{~m} 2: 3$ lantai

$\mathrm{BC}=3.538,56 \mathrm{~m} 2$

- $\mathrm{BC}: \mathrm{OS}=40: 60$

$\mathrm{BC} \times 60=\mathrm{OS} \times 40$

$3.538,56 \times 60=$ OS $\times 40$

$212.313,6=$ OS $\times 40$

$212.313,6 / 40=$ OS

$$
5.307,84 \mathrm{~m} 2=\mathrm{OS}
$$

Luas lahan yang tidak terbangun $(\mathrm{OS})= \pm$ $5.307,84 \mathrm{~m} 2$

- Luas Site $=B C+O S+$ Luas Parkir $=3.538,56 \mathrm{~m} 2+5.307,84 \mathrm{~m} 2+$ $5.447,5 \mathrm{~m} 2$

$=24.293,9 \mathrm{~m} 2 \sim \pm 2,5 \mathrm{Ha}$ (Alternatif Tapak 1)

4. Organisasi Ruang a) Kelompok Ruang Pelayanan Umum

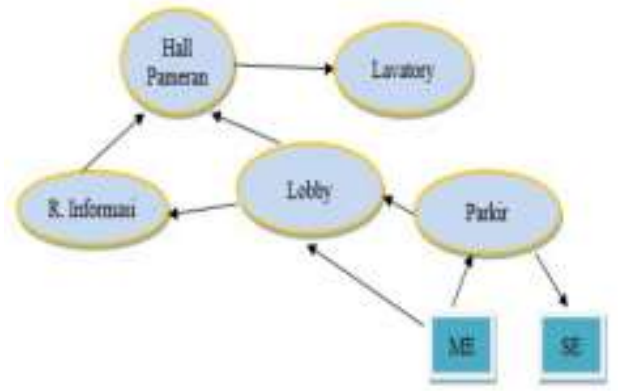

Gambar 14. Skema kelompok ruang pelayanan umum (Sumber: analisis penulis, 2020)

b) Kelompok Ruang secara Makro

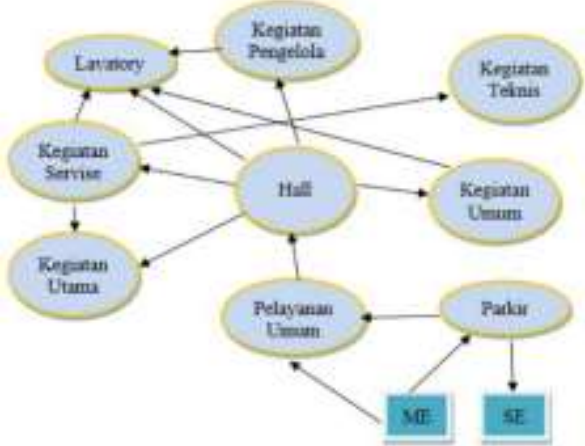

Gambar 15. Skema kelompok ruang secara makro (Sumber: Analisis Penulis 2020)

c) Kelompok Ruang Pengelola

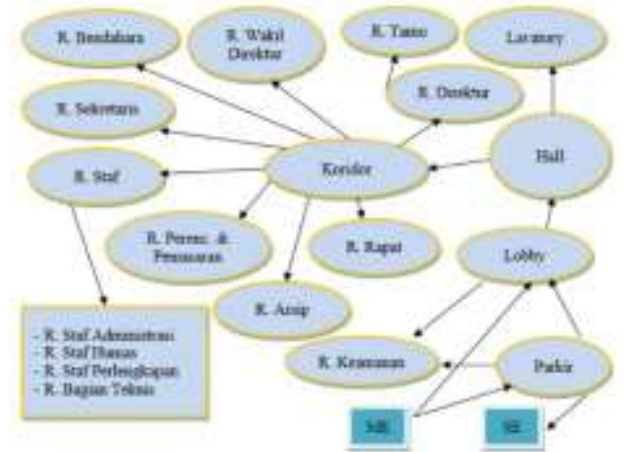

Gambar 16. Skema kelompok ruang pengelola (Sumber: Analisis Penulis 2020)

d) Kelompok Ruang Kegiatan Utama

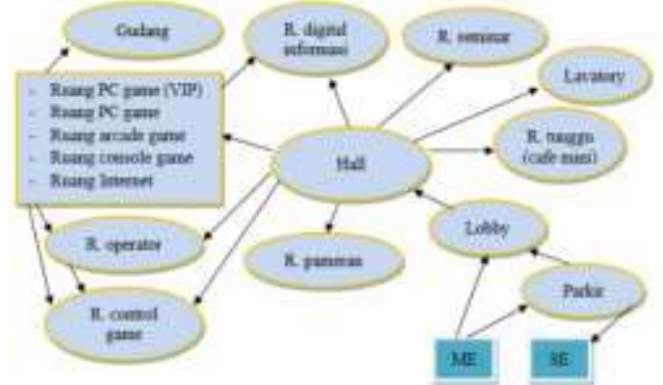

Gambar 17. Skema kelompok ruang kegiatan utama (Sumber: Analisis Penulis 2020)

e) Kelompok Ruang Kegiatan Umum 


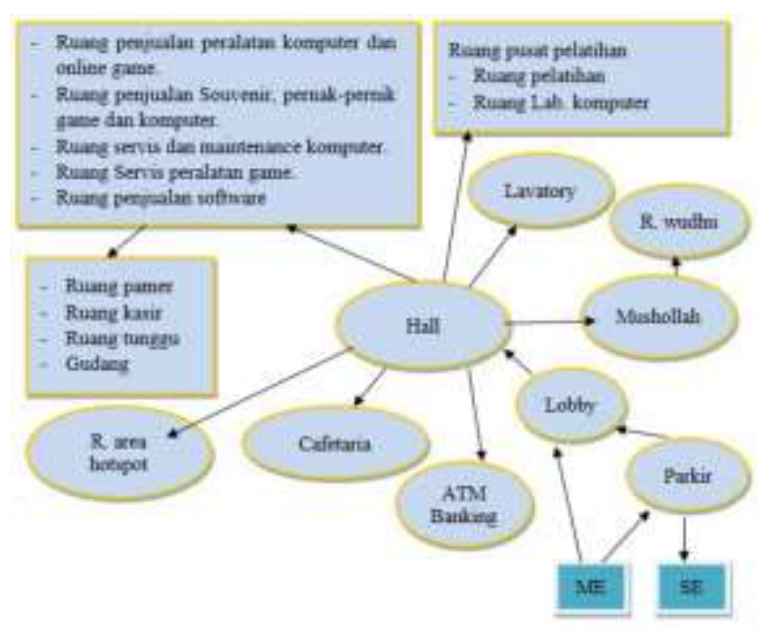

Gambar 18. Skema kelompok ruang kegiatan umum (Sumber: Analisis Penulis 2020)

f) Kelompok Ruang Area Teknis

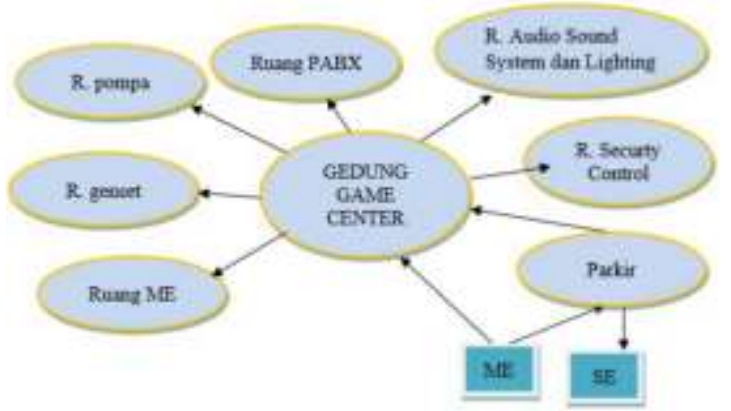

Gambar 19. Skema kelompok ruang teknis (Sumber: Analisis Penulis 2020)

g) Kelompok Ruang Area Servis

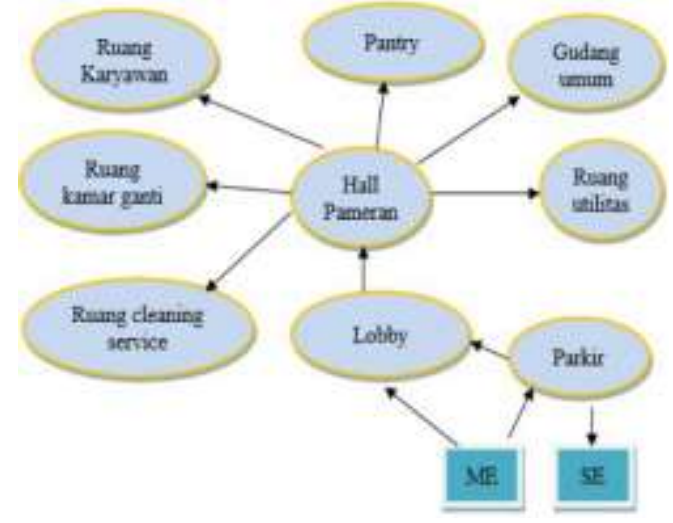

Gambar 20. Skema kelompok ruang servis (Sumber: Analisis Penulis 2020)

\section{Konsep Ruang Dalam}

Dalam Perancangan ruang dalam Perlu kita ketahui untuk menghasilkan kenyamanan dalm ruang dalam hal mencapai harmonisasi dan keseimbangan dapat dicapai dengan menerapkan beberapa alemen dasar perancangan ruang dalam, yaitu bidang, cahaya, udara, warna, tekstur, dan akustik.

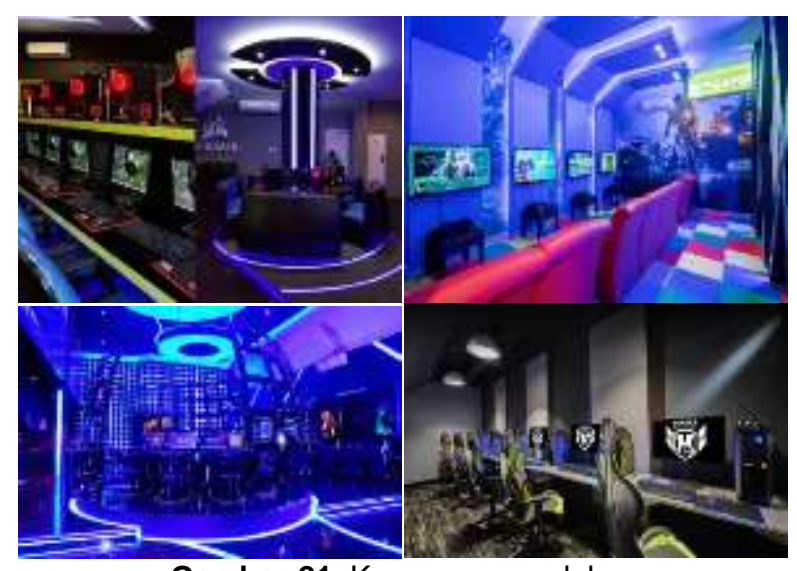

Gambar 21. Konsep ruang dalam

(Sumber: Analisis Penulis 2020)

6. Konsep Ruang Luar

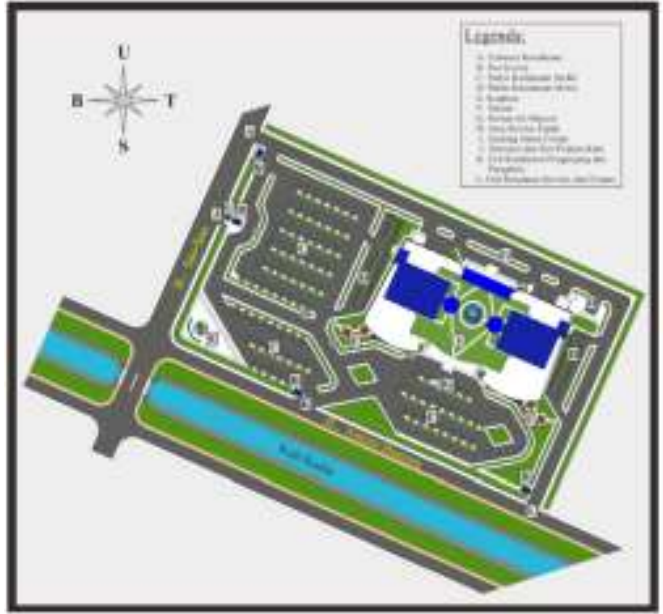

Gambar 22. Blok Plan Tapak

(Sumber: Analisis Penulis 2020)

Ruang Luar di bedakan menjadi dua, yaitu:

1) Ruang luar aktif adalah rung luar yang digunakan untuk mendukung kegiatan yang ada dalam tapak, yaitu pengadaan sirkulasi, lahan parkir, pelaza, dan pergola

2) Ruang luar pasif adalah ruang luar yang biasnya digunakan sebagai lahan hijau, untuk resapan air, meredam kebisingan, pengara sirkulasi, dan untuk tempat perletakan lampu tamn untuk penarangan tapak.

Dalam penataan ruang luar yang perlu diperhatikan adalah penggunaan soft material dan hard material, karena dalam pengolahan landscape pada area Gedung Pusat Kreativitas penggunaan bahan soft material dan hard material adalah penentu kenyamanan ruang luar bangunan.

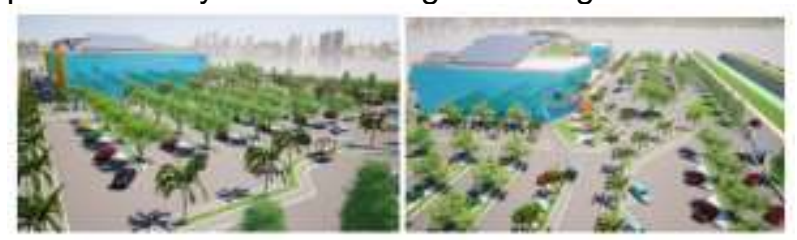

Gambar 23. Soft Material

(Sumber: Analisis Penulis 2020) 


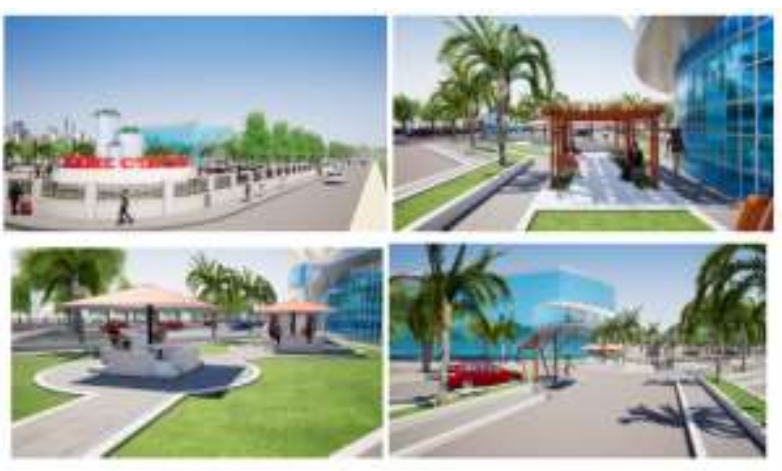

Gambar 24. Soft Material

(Sumber: Analisis Penulis 2020)

7. Konsep Struktur

Dalam penataan sistem struktur yang perlu diperhatikan adalah penggunaan struktur atap, super struktur dan sub struktur agar mendapatkan sistem struktur yang tepat dan efektif untuk memikul beban yang bekerja serta kondisi tanah yang ada, dan sangup menyesuaikan rancangan bentuk yang diinginkan.

a) Core

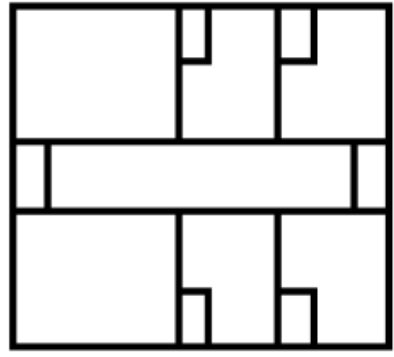

Gambar 25. Struktur Core

(Sumber: Analisis Penulis 2020)

b) Struktur Atap

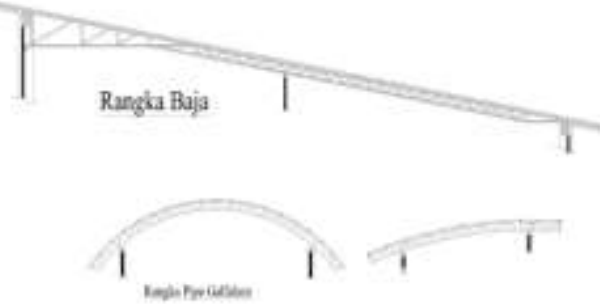

Gambar 26. Struktur Rangka Atap Join Bool dan Rangka Baja

(Sumber: Analisis Penulis 2020)

c) Super Struktur

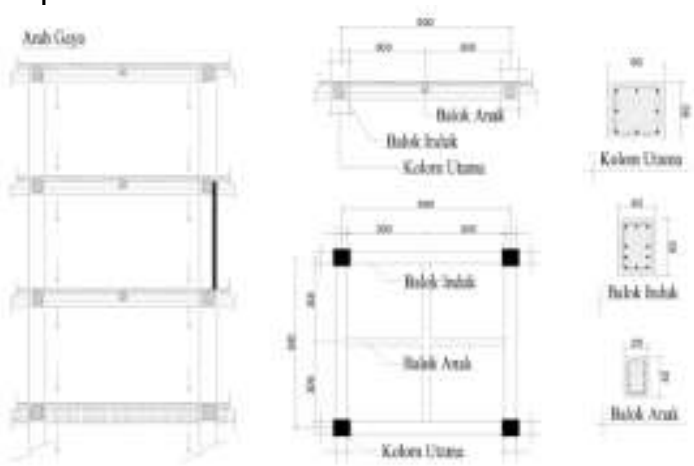

Gambar 27. Super Struktur Balok, Plat,dan Kolom (Sumber: Analisis Penulis 2020) d) Sub Struktur

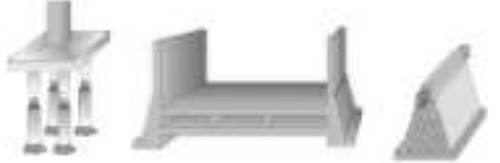

Gambar 28. Sub Struktur Pondasi Pancang, Pondasi Rakit dan Pondasi Garis

(Sumber: Analisis Penulis 2020)

e) Tampilan Struktur Gedung kreativitas dan Kantaor Pengelola

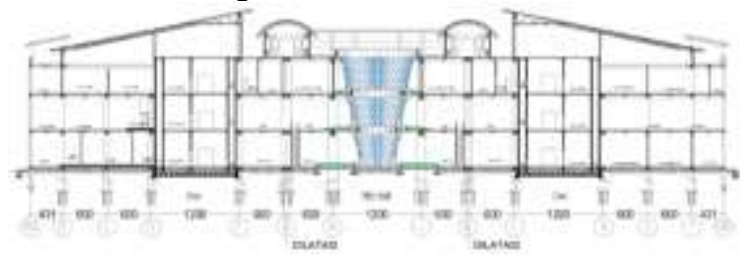

Gambar 29. Out- put Struktur Gedung Game Center (Sumber: Analisis Penulis 2020)

8. Konsep Sistem Utilitas

a) Sistem Plumbing dan Sanitasi

1) Sistem distribusi air bersih

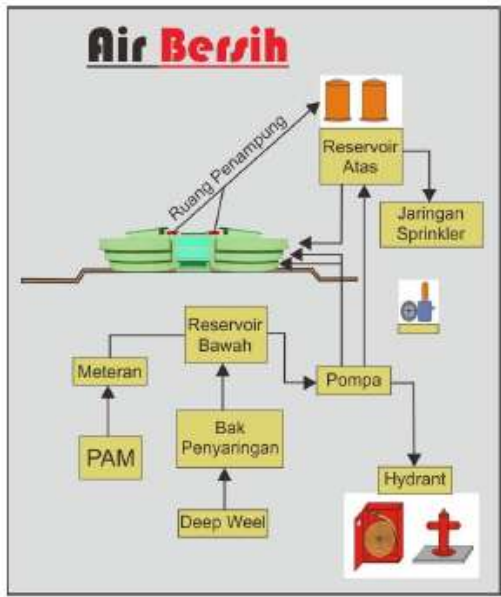

Gambar 30. Sistem Distribusi Air Bersih (Sumber: Analisis Penulis 2020)

2) Sistem Pembuangan Air Kotor Padat dan cair

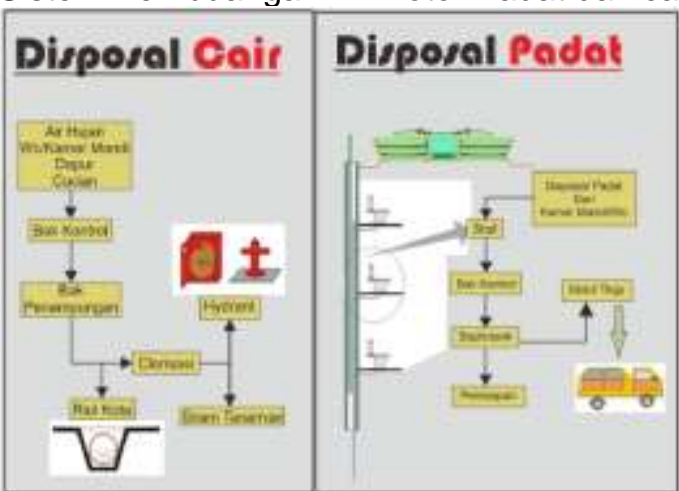

Gambar 31. Sistem Pembuangan Air Kotor padat dan Cair

(Sumber: Analisis Penulis 2020) 
b) Sistem Pencegah Kebakaran

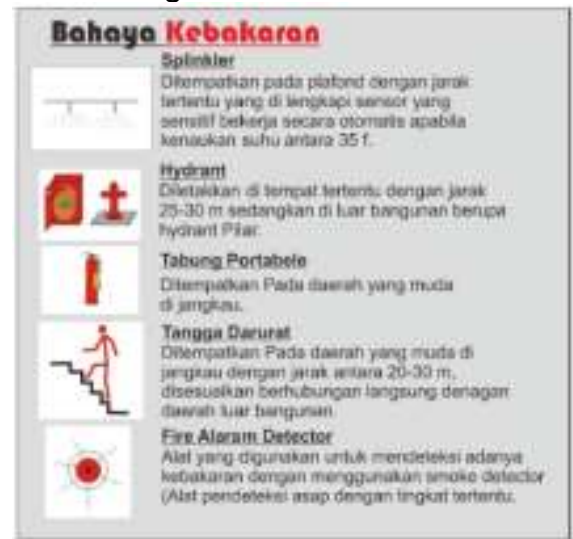

Gambar 32. Sistem Pencegah Kebakaran (Sumber: Analisis Penulis 2020)

c) Sistem Kelistrikkan

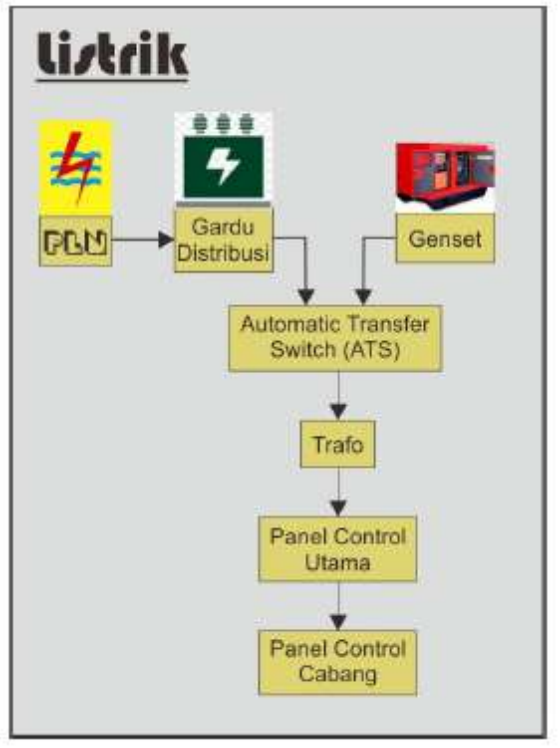

Gambar 33. Sistem Kelistrikkan

(Sumber: Analisis Penulis 2020)

d) Sistem Keamanan Dalam Bangunan

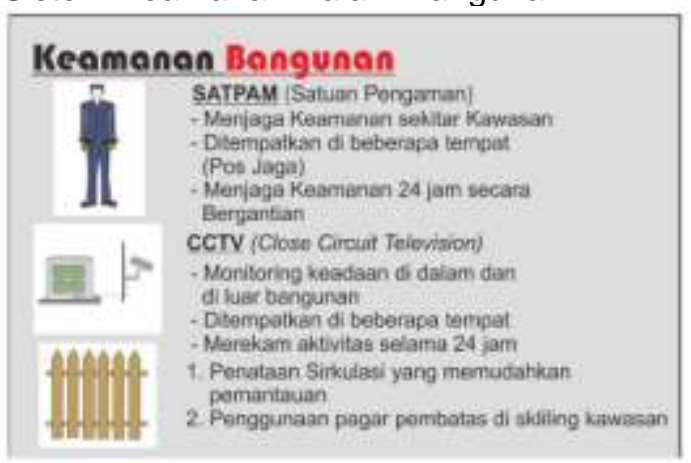

Gambar 34. Sistem Tata Suara

(Sumber: Analisis Penulis 2020) e) Sistem Penangkal Petir

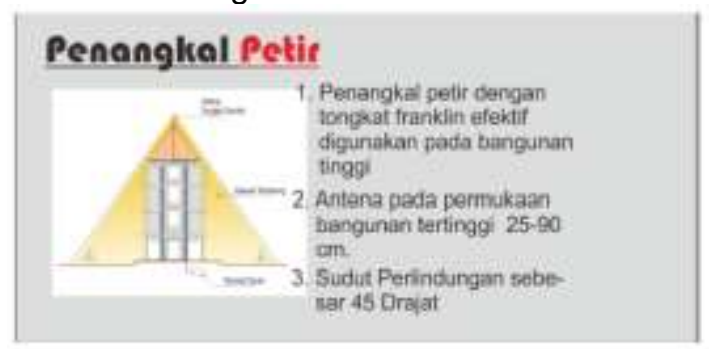

Gambar 35. Sistem Penangkal Petir

(Sumber: Analisis Penulis 2020)

f) Sistem Transportasi Dalam Bangunan

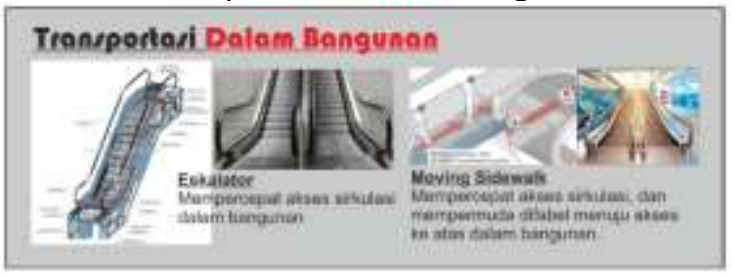

Gambar 36. Sistem Transportasi Dalam Bangunan (Sumber: Analisis Penulis 2020)

g) Sistem Persampahan

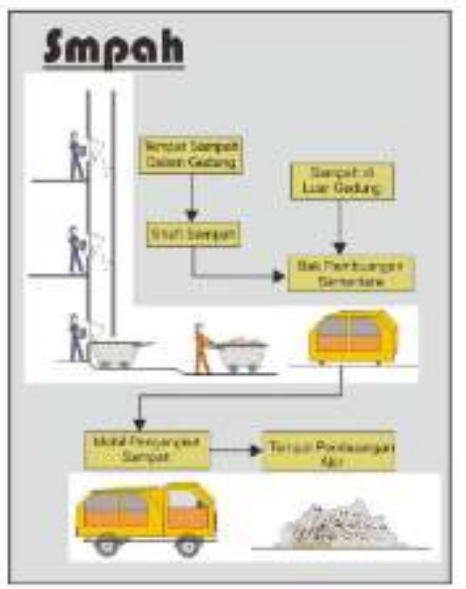

Gambar 37. Sistem Persampahan

(Sumber: Analisis Penulis 2020)

\section{KESIMPULAN}

"Perencanaan Game Center di Kendari dengan pendekatan Arsitektur Morphosis" dapat disimpulkan sebagai berikut:

1) Lokasi terletak di pusat kota Kendari tepatnya di Kec. Kadia, Kel. Bende, JIn. Sao-sao sesuai dengan peruntukkan lahannya sebagai zona perdagangan dan jasa dengan perencanaan Game Center dipusat kota Kendari, lokasi terpilih karena potensi sekitar tapak berdekatan dengan target pasar yaitu sekolahsekolah yang berada di kawasan tersebut saling berdekatan, kepadatan penduduk, fasilitas penunjang sekitar tapak,

2) mudah terlihat oleh banyak orang, serta akses jalan yang mudah di capai.

3) Pengolahan tapak atau site dilakukan untuk mengetahui potensi - potensi yang ada di sekitar tapak yang dapat mendukung 
perencanaan Game Center di Kendari dengan pendekatan Arsitektur Morphosis. Potensi potensi yang di analisis yaitu orientasi matahari dan arah angin, sudut pandang atau view, Sumber kebisingan atau noice, sirkulasi baik kendaraan maupun pejalan kaki, serta ketersediaan jaringan utilitas kota di sekitar tapak.

4) Perancangan mikro pada perencanaan Game Center di Kendari dengan pendekatan Arsitektur Morphosis yaitu kebutuhan dan pengelompokkan ruang, besaran ruang, organisasi ruang, serta hubungan ruang agar menfasilitasi semua kegiatan game dalam perencanaan gedung. Perancancangan di lakukan dengan mengikuti prinsip form follow the fungtion atau bentuk mengikuti fungsi serta rancangan yang disusun berdasarkan standarstandar arsiktektural.

5) Penentuan bentuk dan penampilan bangunan game center dengan pendekatan arsitektur morphosis di Kendari di dasarkan pada pertimbangan fungsi dan ekspresi dalam kaitannya dengan nilai-nilai arsitektur Morphosis, yaitu desain bangunan yang terkesan international karena dalam penerapan bentuk bangunan merupakan hasil pemikiran perancang tanpa menjadikan bangunan traditional tertentu sebagai studi banding. Dari luar bangunan gedung game center ini terkesan unik, pada salah satu bagian sisinya tampak seperti ada bingkai raksasa yang menempel di dinding gedung. Bingkai raksasa ini menambah tampilan gedung semakin menarik.

\section{DAFTAR PUSTAKA}

Ching, F. D. (2008). Arsitektur Bentuk, Ruang, dan Tatanan Edisi ketiga.

Hardani, W. (2002). Ernst Neufert Data Arsitek, Edisi 33, Jilid II.

Muhammad, R. (2018). PONTIANAK GAME CENTER. Jurnal online mahasiswa Arsitektur Universitas Tanjungpura, 4354.

Nashruddin, I. I. (2013, April 11). Transformasi Bentuk dalam Arsitektur. Retrieved from blogspot.com: http://kanvasangan. blogspot.com/2013/04/transformasibentuk-dalam-arsitektur.html, jam 13:31

Tisnawati, A. A. (2014). Sejarah Konsep Tata Cahaya, Warna, Tekstur dan Pola Standardisasi Istilah Interior ( Teori Interior). 